\title{
A study of figurative languages in the poem Kepada Semua Perempuan yang Membawa Luka Hati written by Asma Nadia
}

\author{
Suprihatien ${ }^{\text {a, }} \mathbf{1}$, Rini Damayanti ${ }^{\text {b, 2*, }}$ \\ ab Universitas Wijaya Kusuma Surabaya, Dukuh Kupang XXV/54, Surabaya 60225 \\ I titien.suprihatien_fbs@uwks.ac.id ; ${ }^{2}$ rinidamayanti_fbs@uwks.ac.id* \\ *korespondensi penulis
}

\begin{tabular}{|c|c|c|}
\hline \multicolumn{2}{|c|}{ Article's information } & \multirow{2}{*}{$\begin{array}{l}\text { ABSTRAK } \\
\text { Tujuan penelitian ada dua yaitu untuk lebih memahami makna atau arti yang }\end{array}$} \\
\hline History: & & \\
\hline Submitted & : I5 Juli 2020 & terkandung dalam karya sastra dan mengenal macam-macam gaya bahasa atau \\
\hline Revised & : 20 April 2021 & metafor yang terdapat pada sebuah karya sastra. Metode deskriptif kualitatif \\
\hline Published & : 30 April 202I & digunakan pada penelitian ini yaitu berupa ulasan atau analisis teks pada puisi \\
\hline \multicolumn{2}{|l|}{$\begin{array}{l}\text { Kata kunci: } \\
\text { makna } \\
\text { gaya bahasa } \\
\text { puisi }\end{array}$} & $\begin{array}{l}\text { Kepada Semua Perempuan yang Membawa Luka Hati Karya Asma Nadia. } \\
\text { Simpulan dari kajian puisi ini adalah bahwa seorang perempuan memang dituntut } \\
\text { untuk lebih tabah, lebih sabar, dan lebih berlapang dada dalam menghadapi segala } \\
\text { sesuatunya. Penggunaan gaya bahasa yang dipakai oleh pengarang dalam menulis } \\
\text { puisi ini juga sudah beragam, sehingga gaya bahasa yang dikaji sudah mewakili } \\
\text { beberapa gaya bahasa yang ada. }\end{array}$ \\
\hline
\end{tabular}

Key word:

meaning

figurative language

poetry

\begin{abstract}
This study aims to better understand the meaning contained in a literary work and to recognize the various figurative languages or metaphors found in a literary work. The qualitative descriptive method used in this study is in the form of a review or text analysis of the poem Kepada Semua Perempuan yang Membawa Luka Hati written by Asma Nadia. This poetry study concludes that a woman is indeed demanded to be more courageous, more patient, and more tolerant in dealing with everything. The figurative language used by the author in writing the poem was also diverse, so it has represented several figurative languages that have been commonly used.
\end{abstract}

\section{Introduction}

Copyright (C) 2018 Universitas Ahmad Dahlan. All Right Reserved

Language is a communication tool used by humans in spoken and written texts. Humans use language when interacting with other social creatures. As social beings, humans talk properly according to the manners of speaking in the society.

As an Indonesian, of course we are proud of Indonesian which is used as the national language in our daily conversation. Indonesian language is not only used as a means of communication, but it is also used as a language in written works. The written works, then, play an important role in pouring beautiful words that are created from memorable events or experiences of a writer, such as novels, short stories, poems, and others.

In this era, writers do not only use print media but also online media. They can upload their writings via internet or social media. Furthermore, there is a figurative language or metaphor in a written work. Metaphor is the use of the richness of language in literary works to get certain impressions in order to make the literary works livelier. It also represents the uniqueness of literary authors and how to express the results of their thoughts and feelings in spoken and written texts.

Metaphor or figurative language is known in rhetoric as style. The word style comes from the Latin word stilus, which means a means which has the function of writing on a plate or wax plate. Furthermore, the term style changes to the ability to write or change a series of beautiful and interesting words (Keraf, 20I0: 122).

Metaphor allows us to judge the personality, temperament, and abilities of a person who uses that language. The better a person's metaphor is, the better other's evaluation of it is; the worse a person's metaphor is, the worse the judgment given to him is (Chaer, 2012). 
Every writer has a different style of language. This can be seen or heard through his/her works. A literary work, like a novel, short story, or poem, must have something in it that can be studied whether it is from the content, the use of the figurative language, or the beauty of the language used in the literary work.

In terms of literary process, the use of metaphors presented in literary works is inseparable from the intelligence and cleverness of the authors in expressing words that have implied or explicit meaning, direct or indirect message. According to Ratna (2013: I4), the authority to use special language in literary process is due to several things, namely: I) literary process requires an element of beauty; 2) in presenting a message, a literary process uses indirect methods, such as: reflection or image, refraction or change, projection or prediction, manifestation or embodiment, and representation or depiction; 3) literary process is a feeling of emotion, not intellectuality.

The element of beauty, consisting of indirect message delivery and emotional outpouring, focuses the use of literary language on forms of presentation that are not visible and wrapped, even deliberately hidden. There is a meaning to get the message, the technique of understanding it is through a long and winding road. In order to get and understand the message hidden in the literary work, an author wraps it through the stylized forms he/she creates. For example, the language in poems often experiences deviations but they can still be understood by the reader(s). What is it for poets write a poem if it is not communicative and it cannot be understood by the readers?

The use of various literary languages used by an author has a purpose, namely the purpose of beauty, which means that in literature the beauty of expression is indeed a point that must be emphasized. Literature is a form of art, so the beauty purpose is important.

Metaphors are differentiated based on several benchmarks of the language elements used, namely figurative language based on the word choice, figurative language based on the tone contained in the discourse, figurative language based on the sentence structure, and figurative language based on the direct meaning (Luqman, 2020).

Authors commonly realize the process of creating metaphors in literary works aims at getting the aspect of beauty. Metaphors play an important role in addition to stylistics, which fall into the category of poem or quotes (words of wisdom). Stylistics is the most important element to identify the characteristics of the language use from an author because, in general, stylistics is mostly discussed in linguistics, especially in the form of descriptions of various types of metaphors as metaphors are related to beauty.

The choice of words used by an author includes various supporting components of the stile, from sound choices, diction, syntactic structures, and various forms of figurative language. According to Nurgiyantoro (2014: 43), a stile in a literary text can be ascertained that it is not just a coincidence, but it must have been chosen through various considerations. There is no such thing as a coincidence in literary language, let alone a poem whose beauty is very much dependent on the choice of language, especially diction. Thus, whether or not the content of meaning, information, or message is delivered, in many ways, depends on the quality of the language used.

An author uses a distinctive figurative language in his/her work. This characteristic is what makes readers interested in reading a literary work created by the author. Every writer has different characteristics in him/her. This can be seen from the literary process he/she makes. The use of metaphors shows the author's soul and personality as a language user.

Figurative languages or metaphors are beautiful words used to enhance emotional effects through introducing and comparing an object with another thing that is more general. The use of a person's richness of language in speaking or writing, more specifically by using a certain variety of language, is to get a certain impression. In this case, the impression is an aesthetic effect that produces artistic value(s).

In accordance with the background described above, the authors of this article studied a poem taken from the novel entitled Catatan Hati Seorang Istri by Asma Nadia. In the novel, there is a poem that caught the authors' attention to examine the use of the figurative languages. The title of the poem is Kepada Semua Perempuan yang Membawa Luka Hati. Therefore, the authors entitled this paper as "A Study of Metaphors/Figurative Languages in the poem Kepada Semua Perempuan yang Membawa Luka Hati written by Asma Nadia". This research article discusses the poem in terms of its meaning and analysis of the figurative languages used by the authors.

Based on the research background, the problem formulation is: What is the meaning of the poem "Kepada Semua Perempuan yang Membawa Luka Hati "? and What is the analysis of the figurative languages in the poem "Kepada Semua Perempuan yang Membawa Luka Hati "?

\section{Method}

This research used a descriptive method. Azwar (20II: 5) explains that the qualitative approach prioritizes its analysis on the deductive and inductive inference processes as well as on the analysis of the dynamics of the relationship between the observed phenomena by using scientific thinking. Qualitative research is used to describe 
or explain the features of social influences that cannot be explained through a quantitative approach (Saryono, 20I0: I). Qualitative research method is a research technique used to examine natural objects and the main key lies in the researcher, and the final result is emphasized on the meaning rather than generalization (Sugiyono, 20I I: 8).

According to Ratna (2013: 39), the descriptive analysis method is the use of techniques by analyzing and deciphering data to describe the state of the research object as the center of attention.

Based on Arikunto (2010), data are the real picture of an incident that still has its raw form so that the incident cannot be told and reprocessed through a stage or a model used to obtain clearer information. The data, in the form of words and sentences in the novel (quotations), collected in this study came from an author named Asma Nadia. The data contain figurative languages based on the theories described previously. The population and sample in this study were a literary work in the form of poem Kepada Semua Perempuan yang Membawa Luka Hati in the novel Catatan Hati Seorang Istri written by Asma Nadia. In line with qualitative descriptive as the research method, this study used a content or textual analysis technique. An analysis is a researcher's technique to find the parts of a literary work in depth.

Data collection technique is a very important step in conducting a study, because collecting data is the main objective carried out strategically when conducting research (Sugiyono, 2012: 224). In this study, the data collection was carried out through several techniques, namely observing, listening, classifying, marking, and recording all the data related to the analysis of figurative languages in Asma Nadia's novel.

\section{Results and Discussion}

\section{A. Meaning behind the Poem}

A writing, a prose, or a poem must have meaning behind it. The meaning can be delivered explicitly or implicitly. The poem Kepada Semua Perempuan yang Membawa Luka Hati in a novel Catatan Hati Seorang Istri by Asma Nadia is loaded by both explicit and implicit meanings.

A language is expressed to create a beautiful expression full of meaning constructed by a lot of elements, and thus can be understood by the readers. The meaning can be divided into two parts, so it will be understood easily.

The poem Kepada Semua Perempuan yang Membawa Luka Hati (Nadia, 2014) encourages women and wives to always be strong and tough facing the trials Allah has given to them. Every household will go through some problems, it is not always rainbows and butterflies. There will always be some big or small ripples and flames.

If a household is going through a problem, the first thing to do is to get closer to Allah because He is the one who allows the trials, and so He will also be the one to offer the way out. There are so many ways to get closer to Allah, by practicing night prayer more often, fasting every Monday and Thursday, and reading Quran and other prayers. These are all done with the intention to talk to Allah, to confide to Allah, and to ask for strength, patience, and great endurance, so it is possible to face the trials.

As a woman and a mother, to have a great endurance, patience, and fortitude is a must, given all the responsibilities hold by a mother. If the household is in dire straits, the children might be losing their guidance. If they lose the father figure, it does not mean they should lose their mother figure too. A mother should have given all the love and attention that is no longer given by the father.

It is indeed true that educating children when a household is on the tip of an iceberg is not easy because the burden will be heavier than the usual. However, it is still a must to be a good, patient, loving, physically and psychology harmless mother. Under this kind of situation, woman's strength is tested, will she be strong enough facing all the obstacles along with the accompanying feelings, the disappointment, sadness, and anger, all at once. A woman will have to continue the struggle(s) so the children will be mentally healthy and they will not be an anger-releasing tool for the parents.

The encouragements and prayers from fellow women and wives are great cures for the women facing trials from Allah so that they will be tough and patient dealing with all the obstacles. Allah allows the trials, and so Allah offers a way out.

\section{B. Analysis of the Figurative Languages in the Poem}

Figurative languages or metaphors are expressions created by an author by using words or sentences to express his/her ideas, thoughts, and experiences to ensure or affect the readers (Damayanti, 2019). Hence, this research discusses some figurative languages used by Asma Nadia in her novel.

\section{Allegory}


As one of the figurative languages, Allegory expresses things with symbols. The symbols here are used as a full comparison. This figurative language is a metaphor of a story or an imagery. It expresses another thing or event. The allegory used by Asma Nadia in the poem is listed in these expressions:

I. Talk and confide to Him more.

2. When given trials by Allah, given a situation that is hard to understand, then talk to Him, confide to him truly. Tell Him about everything, ask for strength to the Almighty. Move your burdens and problems on your shoulders to Him.

3. Can she, in her disappointment, anger, and sadness, play the best mother role? To continue playing, to continue struggling, so the children can be mentally healthy, growing under a complete circumstance, even if the household is a mess.

4. May Allah shower the beloved children with love as wide as an ocean.

In the parable of getting problems, the main thing to do is to get closer to Allah because he puts us into the trials, so he will be the one to let us out of the problems too. It is like a padlock comes with a key. There are a lot of ways to get closer to Allah. These are all done with the intention to talk, to confide to Allah, to ask for strength so the trials can pass in ease, with patience and fortitude.

\section{Asyndeton}

In portraying the settings, describing the places, telling the stories, outlining the problems, Asma Nadia as the author used asyndeton. It is a figurative language to affirm something by stating things, objects, or situations successively. Asyndeton was used by the author to portray a situation accordingly, and thus the effects stand out. These are the expressions:

5. Dear fellow women, it is very important for us to seek for spiritual condition, when a heart is going through a trial.

6. When problems hit, practice night prayer more, fast every Monday and Thursday, practice other prayers like reading Quran.

7. Talk and confide to Him.

8. When given trials by Allah, given a situation that is hard to understand, then talk to Him, confide to him truly. Tell Him about everything, ask for strength to the Almighty. Move your burdens and problems on your shoulders to Him.

9. By doing so, hopefully the energy drained by facing the problems will soon recover.

I0. Even being a good, patient, loving, harmless, even as small as pinching the children's ears, is not easy.

Asyndeton is pretty solid, meaning that the words, phrases, clauses are not separated by conjunctions (Chaer \& Leonnie, 20I4), thus every word or phrase can only be separated by a comma accordingly. Thus, in the poem, Asma Nadia emphasized to confide to Allah for every trial faced by humans.

\section{Association}

Association belongs to a comparative figurative language. It compares one situation to another based on the characteristics of the situation itself. The data are below.

II. Cry, lament. Move your burden on your shoulders to Him.

12. Younger or older, children will always need their mother to be the sun whenever the day is dark, and provide warmth when the wind feels cold.

13. Their happiness is in our hands, mothers. May Allah shower the beloved children with love as wide as an ocean.

Asma Nadia used association to compare ideas or thoughts, so the message(s) became more compelling, like "to move the burden on our shoulders to His shoulders".

\section{Personification}

Personification is a figurative language where we compare an inanimate object as if it is alive and acts like human.

I4. May Allah give greater patience, may Allah pour love from the fingers of the mothers who survive from trials, to fill up the children with even more love.

I5. Younger or older, children will always need their mother to be the sun whenever the day is dark, and provide warmth when the wind feels cold.

16. Their happiness is in our hands, mothers. May Allah shower the beloved children with love as wide as an ocean.

Asma Nadia beautifully personified her fingers to be able to pour love through her writing.

The use of this figurative language needs the author's sensitivity. The author should be able to sort and pick the right expressions, including to personify something. This accuracy will affect the effectiveness of the messages delivered to the readers. 


\section{Repetition}

What is meant by repetition is to repeat one word over and over again in the same sentence.

17. Can she, in her disappointment, anger, and sadness, play the best mother role?

18. To continue playing, to continue struggling, so the children can be mentally healthy, growing under a complete circumstance, even if the household is a mess.

19. May Allah give greater patience, may Allah pour love from the fingers of the mothers who survive from trials, to fill up the children with even more love.

20. Despite our much negligence, despite our never ending sins, despite our piling mistakes. Amen.

Repetition was used by Asma Nadia to emphasize words or sentences considered important. The words

"May Allah" was repeated over and over again to emphasize its importance.

\section{Rhetoric}

Rhetoric seems like a question when it actually does not need an answer because it is already acknowledged. According to Septira (2019), Rhetoric is a figurative language used to express something directly based on the literal meaning to get a certain effect so the listener or reader will understand the meaning in spoken or written text, directly or indirectly. Based on the data found, the researcher found the rhetoric data listed below.

2I. Can she, in her disappointment, anger, and sadness, play the best mother role?

22. To continue playing, to continue struggling, so the children can be mentally healthy, growing under a complete circumstance, even if the household is a mess.

Erotesis or rhetorical question is a question to someone who actually does not need an answer and can only be answered with possibly one word only.

Rhetoric is used to get a certain effect wanted by the author. The effect probably makes the reader cry, feeling touched, or sad.

\section{Simile}

Simile is a figurative language using direct or explicit comparison to match one thing to the comparison itself. This figurative language commonly uses words as the sign(s) of the accuracy of the comparison. These words include like and as.

23. Pay close attention, love them. Children are the media for us to get to Allah's heaven through devotion and dedication as a mother to them.

24. Can she, in her disappointment, anger, and sadness, play the best mother role?

25. And not using the children as a media to vent anger to the partner.

Asma Nadia used a direct and straightforward comparison in her novel. She used it wisely in the word choice in her novel.

From the figurative languages used, either the meaning is directly delivered or not is affected by some functions. The word choice or diction in the poem portray a better and lively image. A suitable figurative language is used to emphasize or against some ideas. The use of the figurative language is to hold the understanding of the reader about the meaning in the poem. The reader will realistically imagine the image of the stories through the author's expressions.

The diction or the choice of words in the poem tend to mirror the courtesy and modesty of the author. Through the literary work she made, Kepada Semua Perempuan yang Membawa Luka Hati, it appears that the author is tough, modest, polite, and broadminded.

\section{Conclusion}

Based on the research results, it is concluded that a woman is required to be more resilient, more patient, and more tolerant in dealing with everything. In this case, the reason lies in the status of a woman. Especially as a mother, a woman is required to pay more attention and love to her children because they will certainly lose the figure of a father if the household is in dire straits. Only upon Allah do we rely on life, surrender ourselves, to be more tawakkul, and of course to increase our faith in Allah. The meaning of poem tends to motivate all women to remain determined in dealing with the life's trials.

The analysis of the use of figurative languages used by the poet in writing the poem has also been varied, so that the figurative language studied have represented several existing figurative languages. There are 7 figurative languages used, namely allegory, asyndeton, association, repetition, rhetoric, and simile. The figurative language is a form of language that creates certain impressions that affect the meaning of the speech.

Asma Nadia is a female writer who emphasizes female characters in every stroke of her works. The woman's side portrayed is the one with great kindness, religiosity, and her fortitude. This is what characterizes every Asma 
Nadia's literary work. In her work, Asma Nadia always includes several hadiths or holy verses as a form of her da'wah in each of her works, including in the poem Kepada Perempuan yang Membawa Luka Hati ini.

\section{Acknowledgement}

My sincere appreciation to those who have supported and were involved in the research and writing of this article, specifically to LPPM UWKS and FBS UWKS colleagues. In addition, the authors also express gratitude to BAHASTRA UAD who has helped and accepted this article.

\section{References}

Arikunto, Suharsimi. (2010). Prosedur Penelitian Suatu Pendekatan Praktik. Jakarta: Rineka Cipta. Azwar, Saifuddin. (20II). Metode Penelitian. Yogyakarta: Pustaka Belajar

Chaer, Abdul. (2012). Linguistik Umum. Jakarta: Rineka Cipta.

Chaer, Abdul dan Leonie Agustina. (20I4). Sosiolinguistik : Perkenalan Awal. Jakarta: Rineka Cipta.

Damayanti, Rini (2019). Gaya Bahasa dalam Wacana Produk Iklan Kosmetik di Facebook. Jurnal Ilmiah Sarasvati, $\mathrm{I}(\mathrm{I})$.

Damayanti, Rini, Suprihatien. 202I. Semantik. Kuburaya : Pustaka Adi Ridwan.

Despriyanti, Risma, dkk. (2018). Analisis Gaya Bahasa pada Puisi Aku Karya Chairil Anwar. Parole (Jurnal Pendidikan Bahasa dan Sastra Indonesia). 2(I).

Hasanah, DU dkk (2019). Analisis Penggunaan Gaya Bahasa pada Puisi Karya Fadli Zon. Kembara : Jurnal Keilmuan Bahasa, Sastra dan Pengajarannya. 5(I).

Keraf, Gorys. (2010). Diksi dan Gaya Bahasa. Jakarta: PT. Gramedia Pustaka Utama.

Khusnin, M. (2012). Gaya Bahasa Novel Ayat-Ayat Cinta Karya Habiburahman El Shirazy dan Implementasinya. Seloka: Jurnal Pendidikan Bahasa dan Sastra Indonesia, I(I): 45-53.

Luqman, Hamid Firdahani. (2020). Analisis Gaya Bahasa Perbandingan dalam Novel Dilan Tahun I99I Karya Pidi Baiq. Jurnal Penelitian, Pendidikan, dan Pembelajaran, I5(20): 5.

Luthfi, Luthfi dkk. (2020) Gaya Bahasa Repetisi Ustadz Adi Hidayat tentang Penyelenggaraan Ibadah dalam Wabah Covid 19. Jurnal Bahastra. 40 (I).

Nadia, Asma. (2014). Catatan Hati Seorang Istri. Depok: Asma Nadia Publishing House.

Nurgiyantoro, Burhan. (20I4). Stilistika. Yogyakarta: Gadjah Mada University Press.

Ratna, Nyoman Kutha. (2013). Stilistika: Kajian Puitika Bahasa, Sastra, dan Budaya. Yogyakarta: Pustaka Pelajar. Saryono. (2010). Metode Penelitian Kualitatif. Bandung. PT. Alfabeta.

Sugiyono. (2010). Metode Penelitian Kuantitatif, Kualitatif, dan R\&D. Bandung: Alfabeta.

Septira, Veppi. Iqbal Hilal., dan Bambang Riadi. (2019). Gaya Bahasa Retoris Novel Rembulan Tenggelam di Wajahmu dan Kelayakannya di SMA. Jurnal Kata (Bahasa, Sastra, dan Pembelajarannya). 7(I): I.

Widyaningrum, H. K \& Hasanudin, C (2019). Bentuk Lokusi, Ilokusi dan Perlokusi siswa dalam pembelajaran tematik. Bahastra. 39 (2): 86 -9I.

Yadafel, Rosalia Imelda, Abdul Hafid. (2020). Analisis Gaya Bahasa Puisi KH Mustofa Bisri. Jurnal Frasa (Keilmuan Bahasa, Sastra dan Pengajarannya). I (I) 